\title{
Odnos istarskih pravaša prema raskolu u Stranci prava Banske Hrvatske 1895.
}

\author{
Prethodno priopćenje \\ Preliminary communication
}

UDK 329(497.5)SP“1895“

\begin{abstract}
U članku se raspravlja o raskolu u banovinskoj Stranci prava do kojega je došlo ujesen 1895. godine. Jedna je stranka raskoljene stranke izdavala svoj dnevni list „Hrvatsko pravo“, a druga svoj dnevni list „Hrvatska domovina“. Tim su raskolom pravaši, kao oporbenjaci, oslabjeli svoj politički utjecaj. Istarski pravaši su ukazivali na štetnost raskola i uzaludno nastojali da se uspostavi ponovno jedinstvo stranke.
\end{abstract}

Ključne riječi: Stranka prava, Ante Starčević, Fran Folnegović, Josip Frank, Vjekoslav Spinčić, Banska Hrvatska, Istra

\begin{abstract}
Pravo ravaška državotvorna misao, začeta i oblikovana političko-programatskim promišljanjima Ante Starčevića i Eugena Kvaternika u Banskoj Hrvatskoj, prihvaćena je postupno i u ostalim hrvatskim zemljama, upravno odvojenima od Banske Hrvatske, tako i Istri (Strčić 1969; 1976/77). Ta njihova odvojenost, potvrđena carskim patentom od 26. veljače 1861., još je izrazitije bila istaknuta Austro-ugarskom nagodbom (1867.), kojom su Dalmacija i Istra pripale austrijskom dijelu Habsburške Monarhije. Takav upravni ustroj ostao je do sloma Monarhije.

Markgrofoviju Istru - prema tom teritorijalno-upravnom ustroju - sačinjavali su poluotok Istra i Kvarnerski otoci Cres, Lošinj i Krk. Prvi hrvatski preporoditelji na istarsko-kvarnerskom području, predvođeni biskupom Jurjom Dobrilom, svoju su narodno-preporodnu djelatnost u kulturnom i političkom smislu očitovali tijekom sedmog desetljeća 19. stoljeća i intenzivirali ju od 1870. izdavanjem lista „Naša sloga“ (Šetić 2005: 10). Bili su nadahnuti štrosmajerovskim duhom. Kao istarski Hrvati, naglašavali su svoju pripadnost južnome slavenstvu, koji na tom istarsko-kvarnerskom prostoru dugo žive i imaju pravo opstati, razvijati se te s ostalim stanovnicima graditi suživot $i$ jednakopravnost. Osvještavali su i poticali svoje sunarodnjake, izložene talijanizaciji, a donekle i germanizaciji, da se suprotstavljaju odnarođivanju, da njeguju svoju materinsku, hrvatsku riječ u govoru, molitvi i pismu, da održe svoje običaje, i na taj način sačuvaju i osnažuju svoj hrvatski identitet. U tom su smislu, djelovali i slovenski preporoditelji u Slovenskom primorju i u slovenskom dijelu Istre.

Iste nevolje, koje su podjednako tištile i Hrvate i Slovence u Istri, i iste potrebe odupiranja njihovu odnarođivanju, upućivali su ih na političku slogu i djelatno zajedništvo. Na što su stalno podsjećali i u nazivima političkih listova "Naša sloga“ i „Edinost“. Imali su oni od 1878. i zajedničku političku organizaciju u Istri Hrvatsko-slovensku narodnu stranku.

$\mathrm{Na}$ toj su političkoj baštini prvog naraštaja hrvatskih preporoditelja u Istri nadograđivali narodno-preporodne i integracijske težnje i njihovi sljednici iz mlađe generacije u društveno-
\end{abstract}


političkom ozračju svojega vremena. Čineći daljnje političke iskorake na istarskoj političkoj sceni, ti mlađi ljudi iz hrvatskih redova ističu jače i jasnije svoje hrvatstvo, naglašavajući da Hrvati čine većinsko stanovništvo Istre i Kvarnerskih otoka. Isticali su da se većina nipošto neće dati ni talijanizirati, ni germanizirati, jer da ima svijest ne samo o sebi samoj, već i o svojoj široj, hrvatskoj narodnoj zajednici kojoj pripada. Prema popisu stanovništva iz 1880. godine, u Istri je živjelo 292.006 žitelja, od toga je bilo 121.732 Hrvata, 43.004 Slovenca, 114.291 Talijana i 12.979 ostalih (Manin 2005: 582).

Vodeći ljudi te mlađe generacije: Vjekoslav Spinčić, Matko Laginja i Matko Mandić isticali su da Istra vidi svoju budućnost u združenju s ostalim hrvatskim zemljama. Budući da su se hrvatske političke stranke, i u Dalmaciji i u Banskoj Hrvatskoj, zalagale za to združenje. Ukazivali su da među banovinskim političkim strankama najhrvatskiju politiku vodi Stranka prava. Znali su da je utemeljitelj te stranke Ante Starčević zagovarao samostalnu, slobodnu i ujedinjenu Hrvatsku, koja bi s Austrijom i Ugarskom imala jedino zajedničkoga vladara, okrunjenog zasebno i hrvatskom kraljevskom krunom. I oni su prihvatili taj pravaški zagovor, postali su pravaši, slijedeći primjer profesora i književnika Eugena Kumičića, istarskog Hrvata, rođenog u Brseču, stalno nastanjenog u Zagrebu.

Prihvativši Starčevićev politički nauk, Spinčić, Laginja i Mandić su i nadalje ostali u redovima Hrvatsko-slovenske narodne stranke, nisu osnivali istarsku Stranku prava, i to iz posve razumljivih razloga. Već postojeća Hrvatsko-slovenska narodna stranka bila je politička zajednica istarskih Hrvata i Slovenaca, izraz njihove političke sloge. Ta je stranka, dobro funkcionirala i sve uspješnije ispunjavala svoje narodnosno-političke zadaće. Osnivanje istarske Stranke prava značilo bi slabljenje pa i nerazborito razbijanje Hrvatsko-slovenske narodne stranke. Lako je bilo pretpostaviti, pa i sa sigurnošću unaprijed znati, da bi se u redove istarske Stranke prava rijetko tko uključio od slovenskih narodnjaka, pogotovo onih iz zapadnog dijela Istre, sklonijih slovenskoj nacionalno-integracijskoj misli. Moglo se realno pretpostaviti da znatan broj hrvatskih narodnjaka ne bi ušao u pravašku stranku. Uz to, osnivanje Stranke prava u Istri ne bi dopustio ni vladajući austrijski režim, koji je smatrao da Istra ne spada u hrvatski državnopravni sklop. Takav stav vladajućeg režima očitovan je i u njegovu represivnom postupku prema Vjekoslavu Spinčiću. Svehrvatsku gospodarsku izložbu je 1891. u Zagrebu, organizirano posjetila i veća grupa istarskih Hrvata, predvođena Vjekoslavom Spinčićem. Tom su prigodom posjetili i Antu Starčevića, ideologa i utemeljitelja Stranke prava u Banskoj Hrvatskoj. Pozdravljajući Starčevića, Spinčić je kazao da ga pozdravlja u ime svih istarskih Hrvata, koji su svjesni da Istra pripada Hrvatskoj i koji žele da se Istra jednom napokon nađe u okviru slobodne, samostalne i ujedinjene Hrvatske, za koju se Starčević, kao političar, najodlučnije bori. Tu su Spinčićevu izjavu prenijele i ondašnje novine. Zbog sadržaja te javno dane izjave, austrijsko je Ministarstvo za bogoštovlje i nastavu kaznilo Spinčića otpustom iz profesorske službe (Šetić 2005: 242).

Spinčić i Laginja su, kao narodnjaci, mislili i djelovali pravaški: oporbeno i odlučno, stalno imajući u vidu one političke ideale za koje se zauzimala banovinska Stranka prava. Bili su oni i narodni zastupnici u Istarskom saboru u Poreču, a od 1891. i zastupnici u Carevinskom vijeću u Beču. Međusobno su blisko surađivali s oporbenim slovenskim zastupnicima Ivanom Nabergojem i drugima te s oporbenim hrvatskim zastupnicima iz Dalmacije, pripadnicima Narodne stranke, a od 1894. pravašima: Jurjem Biankinijem, Virgilom Perićem i Nikolom Daparom.

Važno je podsjetiti da su Spinčić, Laginja i njihovi politički istomišljenici u Istri cijenili i razumjeli značaj općehrvatskih, gospodarskih i kulturnih skupova. Ti su skupovi, povezujući Hrvate iz razdvojenih hrvatskih zemalja, doprinosili emotivnoj integraciji Hrvata i jačanju njihove političke svijesti o važnosti stalne težnje prema postignuću hrvatske teritorijalne $\mathrm{i}$ narodne cjelokupnosti. Istarski su Hrvati koje su poticali Spinčić i Laginja i njihovi politički 
istomišljenici pravaške orijentacije, rado sudjelovali u takvim susretima. Osim gospodarske izložbe 1891. u Zagrebu, bili su na proslavi otkrića Kačićeva spomenika 1890. u Makarskoj i Gundulićeva spomenika 1893. u Dubrovniku (Milovan et al. 2008: 227-258).

Istarski su pravaši surađivali i s banovinskim i s dalmatinskim pravašima. Prvi zajednički radni susret pravaških predstavnika iz Istre, Banske Hrvatske i Dalmacije bio je 1892. u Rijeci, u kući Erazma Barčića, gdje su se dogovorili da organiziraju prikupljanja novca, potrebnog za izgradnju Doma Ante Starčevića. ${ }^{1}$

Tadašnje političko ozračje bilo je vrlo teško. Banska Hrvatska pod presijom ugarskoga režima, a Istra i Dalmacija pod presijom austrijskoga režima. U Istri je carevala prevlast Talijana i protalijana, u Dalmaciji je dominirala svemoć austrijske birokracije, u Banskoj Hrvatskoj je kulminiralo mađarsko ugnjetačko tutorstvo, obilježeno vladavinom bana Kârolyja Khuen-Héderváryja, koji se osobito okomljivao na hrvatske oporbene stranke: Stranku prava i Neodvisnu narodnu stranku, s ciljem da ih uništi. Te su stranke u jednom razdoblju bile snažno prisutne u Hrvatskome saboru. Od godine 1884. Stranka prava je imala 24, a Neodvisna narodna stranka 13 zastupničkih mandata. Kasnije, u saborskim izborima, zbog režimskog, khuenovskog izbornog bezakonja te su stranke jako oslabile. Recimo, da se na izborima 1892. godine Neodvisna narodna stranka nije ni pojavila, a Stranka prava je uspjela izboriti tek osam zastupničkih mandata (Perić 2009: 29 i 32).

Da bi postali jači u političkom životu Banske Hrvatske, pravaši i narodnjaci su stupili u pregovore o međusobnoj suradnji i o mogućem udruživanju. To je bilo moguće na osnovi zajedničkog programa, koji je valjalo utanačiti. Takav program je pretpostavljao da i jedna i druga pregovaračka strana odstupe od nekih dotadašnjih stavova, što je i učinjeno. Pravaši su pristali da samostalna, slobodna i ujedinjena Hrvatska, za koju su se zalagali, bude u okviru Habsburške Monarhije, a neodvišnjaci su usvojili pravaški zahtjev da se u toj budućoj hrvatskoj državi nađu i Bosna i Hercegovina, kao i slovenske zemlje, ako to budu željele. Zajednički pravaško-neodvišnjački program (koji su, do udruživanja, pravaši smatrali programom Stranke prava, a neodvišnjaci programom Neodvisne narodne stranke) konačno je bio dogovoren u travnju 1894.

Program je sadržavao sljedeće odrednice: Hrvatska će „sjedinjena opozicija, stojeći na temelju državnoga prava i narodnoga načela, raditi svim zakonitim sredstvima da se narod hrvatski, koji stanuje u Hrvatskoj, Slavoniji i Dalmaciji, u Rijeci, Međimurju, Bosni, Hercegovini i Istri, sjedini u jedno samostalno državno tijelo u okviru Habsburške Monarhije“ i pritom „podupirati svom snagom i nastojanje braće Slovenaca da se slovenske zemlje ovomu državnome tijelu prikupe“. Sjedinjena hrvatska opozicija želi da se „Kraljevina Hrvatska uredi kao pravna država“ i to „ustavno i slobodno (...) po načelima parlamentarne vladavine“, da Hrvatski sabor vrši „zakonodavnu vlast sporazumno sa krunom“ i da „na čelu parlamentarne vlade stoji ban kraljevine Hrvatske“, da zajedničke poslove u Monarhiji, na osnovi Pragmatičke sankcije, zajednički dogovaraju Kraljevina Ugarska i ostale zemlje „Njegova Veličanstva“, da se „ustav, sloboda i nezavisnost Kraljevine Hrvatske oživotvori svim zakonitim jamstvima, napose slobodnim izbornim redom, pravom sakupljati se i sastajati se, te slobodom savjesti, govora i štampe". Provedba ovog programa povjerava se eksekutivnom odboru, koji može dozvoliti sudjelovanje u tom radu i drugim otačbenicima ako i nisu članovi stranke" (Perić 2009: 156).

Utemeljitelj i vođa Stranke prava, Ante Starčević, čitavim je svojim životom bio okrenut političkom, publicističkom, saborskom i stranačko-rukovodećem radu. Trajno je ostao neženja te živio sâm u vrlo skromnim uvjetima, gotovo siromaški. Kao samac stanovao je u malom stanu u Kukovićevoj ulici (u središtu zagrebačkog Donjega grada), gdje je često primao na razgovor pravaše iz raznih hrvatskih krajeva. Pravaši su ga međusobno prisno nazivali pridjevkom Stari po skraćenom obliku njegova prezimena. Dom, koji su pravaši podigli i iz zahvalnosti njemu darovati, imao je stambeni prostor za njegove životne potrebe i prostorije za pravaške skupne sastanke i za uredništvo stranačkog glasila. 
Utemeljitelj i nedvojbeni autoritet Stranke prava Ante Starčević nije sudjelovao u sastavljanju, pravaško-neodvišnjačkog programa, iako je bio upoznat s tijekom njegova sastavljanja. Bio je u to vrijeme već poprilično bolestan i izvan javne aktivnosti. Na hrvatskoj političkoj sceni slovio je još "samo (kao) veliko ime“ (Horvat 1990: 381). U Stranci prava glavnu riječ su tada vodili Fran Folnegović i Josip Frank. I jedan i drugi željeli su sa Stranke prava ukloniti stigmu veleizdajništva, kojom su je označili vladajući čimbenici zbog njezina zalaganja za samostalnu, slobodnu i ujedinjenu Hrvatsku izvan Habsburške Monarhije. Ta se stigma, dakle, mogla skinuti jedino ako bi se Stranka prava, deklarativno i djelatno, opredijelila za upravni ustroj buduće cjelokupne Hrvatske u okviru Monarhije. Folnegović i Frank zbog toga su se založili za upravo takav zajednički pravaško-neodvišnjački program, kakav je bio utanačen. Taj je zajednički program imao i druge namjere, napose onu da se Neodvisna narodna stranka utopi u stranku pravaškog nazivlja. Isto tako, očekivali su da će se s tim programom steći popustljiviji odnos vladara i masovnu naklonost biračkog tijela te da će zagovornici tog programa uskoro postati zastupnička većina u Hrvatskom saboru, i s te pozicije voditi djelotvorniju politiku u interesu hrvatskoga naroda.

S obzirom na Starčevićevu bolest i zbog toga stvarnu izopćenost iz rukovođenja Strankom prava, kao i s obzirom na to da se prema svim znacima mogla očekivati i njegova skora smrt, Folnegović je s punim uvjerenjem držao da bi njemu trebala pripasti funkcija predsjednika Stranke prava. Na tu je funkciju novog pravaškog vođe, Starčevićeva nasljednika, reflektirao podjednako tako i Josip Frank. Njihovo suparništvo uvelo ih je u međusobnu netrpeljivost, koja se postupno i sve vidljivije prenosila i na ostale prvake stranke. Većina tih prvaka davala je prednost Folnegoviću, koji je, kao pravaš, još od 1875. bio saborski zastupnik te svojom tiskanom riječju, prepiskom i neposrednim osobnim kontaktima širio pravaštvo $i$ izvan Banske Hrvatske. Frank se uključio u Stranku prava, 10. prosinca $1890 .^{2}$ Znajući da mu je to otežavajuća okolnost, nastojao je, da što više ugodi Anti Starčeviću i da mu ovaj svojim ugledom i utjecajem bude podrška. Toj je ambiciji trebala poslužiti Frankova izuzetno velika angažiranost oko izgradnje Doma Ante Starčevića i njegovo ciljano prijateljevanje sa Starčevićem, izraženo i kroz razne oblike skrbničke pažnje.

Istarski su pravaši jako držali do prvog pisanog pravaškog programa iz 1894. godine. Dotada, takvog programa nije bilo. Ali, dakako, znalo se, što Stranka prava hoće, kao državotvorna stranka, čemu teži i kakvu državotvornu koncepciju zagovara. To što je ona htjela i za što se zalagala, moglo se čitati i iščitavati u njezinim programatskim „spisima, izbornim proglasima i saborskim adresama" (Matković 2001: 39). Kad god je Stranka prava, počevši od njezina postanka, i dalje, spominjala "narod hrvatski“ $\mathrm{i}$ „,cjelokupnost Hrvatske“, u tom je narodu uvijek vidjela i istarske Hrvate, kao što je i u cjelovitosti hrvatskoga teritorija uvijek vidjela i Istru. Ovaj se put, u njezinom prvom pisanom programu, ne govori više uvijeno (kao ranije kad je bila pod stigmom veleizdajništva), već potpuno jasno i konkretno: da i Istra - „na temelju državnog prava i narodnoga načela" - spada u hrvatsko "državno tijelo".

Nakon utanačenja zajedničkog pravaško-neodvišnjačkog programa trebala ga je, da bi postao pravovaljan, prihvatiti skupština Stranke prava i Neodvisne narodne stranke. Skupština Stranke prava sazvana je za 26. lipnja 1894. u Zagrebu. Tog je dana, s početkom u 9 sati, izvršeno svečano postavljanje kamena-temeljca Domu Ante Starčevića, ${ }^{3}$ a potom je, s početkom u 10 sati, u Streljani, održana skupština Stranke prava, na kojoj je prihvaćen program te stranke. ${ }^{4} \mathrm{Na}$ ovoj su skupštini, osim predstavnika pravašâ iz Banske Hrvatske,

Hrvatska, Zagreb, br. 284, 1890., 1.

Hrvatska kruna, Zadar, br. 12 - 13, 1894., 1.

4 Taj je program prihvatila i Neodvisna narodna stranka na njezinoj skupštini, održanoj 25. listopada 1894. u Zagrebu. - Obzor, Zagreb, br. 246, 1894., 3. 
sudjelovali i predstavnici pravašâ iz Dalmacije, Istre, Bosne i Hercegovine i slovenskih zemalja, kao i predstavnici Hrvatskog kluba u Dalmatinskom saboru iz Zadra. ${ }^{5}$ Predsjednik tog Hrvatskog kluba, Juraj Biankini, je bio i zastupnik u Carevinskom vijeću u Beču i urednik zadarskog "Narodnog lista“. Tom je prigodom izjavio kako Hrvatski klub i Narodni list prihvaćaju program Stranke prava i da će nadalje djelovati u duhu načelâ, sadržanih u tom programu. ${ }^{6}$ Predstavnik slovenskih liberala, veliki pristaša pravaša, Ivan Tavčar, pozdravio je tu skupštinu i rekao: „Slovencem nije spasa nego u državnoj zajednici s Hrvatskom, inače da bi se morali utopiti ili u njemačko more ili u talijansku pustoš“. Uvjeren je da je „ujedinjena i slobodna Hrvatska Slovencem najsigurnije utočište“ i da zbog toga s takvom Hrvatskom „oni hoće podpuno stopljenje“. ${ }^{7}$

Istarske je pravaše na skupštini održanoj 26. lipnja 1894. predstavljao Vjekoslav Spinčić. U svom je govoru naglasio da istarski pravaši s najvećim oduševljenjem odobravaju program Stranke prava. Predložio je i rezoluciju, koju je skupština aklamacijom prihvatila. Ta rezolucija glasi: „1. Sakupljene pristaše Stranke prava proglašavaju Klub Stranke prava u Zagrebu, ${ }^{8}$ kojega dosadašnji rad odobravaju, maticom Stranke prava i vođom jedinstvene akcije u čitavoj otačbini, dočim se klubovom u pojedinih pokrajinah hrvatske države prepušta da udese svoj rad onako kako drže da je najshodnije prema programu Stranke prava. ${ }^{9} 2$. Sakupljeni pristaše Stranke prava hvale i preporučuju kano vriedne drugove i pomoćnike glavnog organa Stranke prava Hrvatske u radu za oživotvorenje pravednih, jedino spasonosnih težnji svih Hrvata, sadržanih u programu Stranke prava: Narodni list, Katoličku Dalmaciju i Crvenu Hrvatsku u Dalmaciji, Hrvatski branik, Posavsku Hrvatsku i Hrvatski narod - u Banovini, Našu slogu, Edinost, II Pensiero Slavo i Slovenski svet - u Trstu, II Rinnovamento i Soču - u Gorici, Slovenski narod - u Ljubljani, i Glas Hercegovca - u Mostaru. 3. Sakupljeni pristaše Stranke prava izrazuju čitavom narodu i svakom pojedincu svoju najtopliju blagodarnost što se uz tolike vlastite potrebe i nevolje ovolikom ljubavi i požrtvovnosti iskazali počast i obezbiedili stare dane prvaku Stranke prava dru Anti Starčeviću“. ${ }^{10}$

Pravaši iz Istre, slovenskih zemalja te iz Bosne i Hercegovine nisu - nakon usvajanja programa Stranke prava - osnivali svoje zemaljske pravaške organizacije, već su i dalje, kao i dotada, s obzirom na specifične prilike u kojima su se nalazili, djelovali kao skupine ili pojedinačno. Prateći rad pravaških prvaka u Banskoj Hrvatskoj, žalostila ih je nesloga koja je vladala među tim prvacima. Suparnički animoziteti između Folnegovića i Franka nisu splašnjavali. Folnegovićevi i Frankovi podržavatelji pronalazili su jedni drugima povode za svoje kritičko komentiranje i političke objede. Uoči sastanka Kluba Stranke prava u Zagrebu, zakazanog za 5. i 6. prosinca 1894., istarski i dalmatinski pravaši, zastupnici u Carevinskom vijeću u Beču: Matko Laginja, Vjekoslav Spinčić, Juraj Biankini, Virgil Perić i Nikola Dapar

$5 \quad$ Hrvatski klub u Dalmatinskom saboru nastao je 1892., kad su šestorica zastupnika (Juraj Biankini, Stjepan Buzolić, Kažimir Ljubić, Josip Paštrović, Virgil Perić i Mate Šarić), nezadovoljni oportunističkim taktizerstvom zastupnika narodnjačke saborske većine, istupili iz Kluba Narodne hrvatske stranke i osnovali taj svoj zasebni klub. - Narodni list, Zadar, br. 36, 1892., 1.

$6 \quad$ Narodni list, Zadar, br. 52, 1894., 1.

Narodni list, Zadar, br. 52, 1894., 2.

8 Pod stranačkim klubom se tada podrazumijevao upravni odbor stranke. U to su vrijeme u klubu banovinske Stranke prava bili najaktivniji Josip Frank, Fran Folnegović i Ivan Ružić.

$9 \quad$ Na osnovi tog stajališta dalmatinski su se pravaši (dotad aktivni u trima skupinama: zadarskoj, splitskoj i dubrovačkoj, i izvan tih skupina - pojedinačno) organizirali kao dalmatinska Stranka prava. Na poziv Hrvatskog kluba, koji se opredijelio za pravaštvo, oni su se sastali 22. kolovoza 1894. u Zadru i tada usvojili Privremenu uredbu dalmatinske Stranke prava. Time su toj stranci „udarili čvrst temelj“. (Narodni list, Zadar, br. 68, 1894., 1). - V. o tome i članak Marjan Diklić, „Stranka prava u Dalmaciji povodom 100. obljetnice osnutka (1894.1994.)“, Radovi Zavoda za povijesne znanosti HAZU u Zadru, 37, Zadar 1995., 779 - 791.

10 Naša sloga, Trst, br. 27, 1894., 1 - 2; Hrvatska, Zagreb, br. 144, 1894., 1. 
uputili su tom Klubu iz Beča svoj apel da se uklone postojeće razmirice u stranci, koje remete njeno jedinstvo i nanose štetu njezinu ugledu. Poznato im je da neki banovinski pravaši ističu kako se „dr. Josip Frank nametnuo stranci za vođu i da je to pogibeljno“. Imajući to u vidu, potpisnici tog apela su naglašavali da ni Frank, ni bilo tko drugi, ne može promijeniti načela stranke. Stranka prava ima svoju „znamenitost i moralnu jakost“ te je, kao takva, moćnija i važnija od bilo kojega pojedinca. ${ }^{11}$

Dana 17. srpnja 1895. izvršena je svečana predaja dovršenog Doma Ante Starčevića Anti Starčeviću kao dar njegovih stranačkih pristaša i drugih pojedinaca iz redova ostalih hrvatskih rodoljuba. Na tu su svečanost došli brojni pravaši ne samo iz Banske Hrvatske, već i iz Dalmacije, Istre, slovenskih zemalja i iz Bosne i Hercegovine. Među sudionicima te svečanosti nalazili su se iz Istre Vjekoslav Spinčić, Matko Laginja, Dinko i Matko Trinajstić te grupa žena i djevojaka iz Voloskog i voloske okolice, koje su uručile Starčeviću svoje prigodne poklone. ${ }^{12}$ Tog je dana u Zagrebu održana i svepravaška skupština na kojoj je izabran Središnji odbor Stranke prava. U taj su Odbor izabrani:

iz Banske Hrvatske - Fran Folnegović, Ivan Ružić, Juraj Žerjavić, Grga Tuškan i Vladimir Kovačević (te zamjenici Eugen Kumičić i Vatroslav Brlić);

iz Istre - Vjekoslav Spinčić (i zamjenik Matko Laginja);

iz Rijeke - Cezar Akačić (i zamjenik Rudolf Linić);

iz Dalmacije - Ante Trumbić i Frano Supilo (i zamjenik Ivo Prodan);

iz slovenskih zemalja - Ivan Tavčar (i zamjenik Gustav Gregorin);

iz Bosne - Miho Babić;

iz Hercegovine - Frano Miličević. ${ }^{13}$

U Središnjem odboru, kako je vidljivo, nije bilo ni Josipa Franka, ni Mile Starčevića, ni nekoga od drugih Frankovih podržavatelja. Kumičić je bio Frankov podržavatelj, ali on je, iz taktičkih razloga, izabran tek za zamjenika, što je moglo imati i zapravo je imalo samo formalnu važnost. Očito je da je Folnegovićeva struja imala prevagu među skupštinarima. Prema ocjeni Folnegovićevih privrženika, ta je skupština označila daljnju etapu u radu Stranke prava i novu „pobjedu hrvatske narodne misli“. ${ }^{14}$

Prevaga Folnegovićeve struje u Stranci prava došla je do izražaja i 16. listopada 1895., kad je birano novo rukovodstvo Kluba te stranke. Za predsjednika Kluba izabran je Folnegović, a za potpredsjednika Grga Tuškan. Za te su funkcije bili kandidirani i Josip Frank i Eugen Kumičić (Frank za predsjednika, Kumičić za potpredsjednika). lako su imali Starčevićevu podršku, izgubili su izbornu bitku. ${ }^{15}$

Takav izborni rezultat snažno je ozlojedio Franka. Otada je dugo i uporno smišljao kako će raskoliti Stranku prava i postati vođa jednoj njezinoj frakciji, zapravo novoj stranci. Čekao je prigodan trenutak ili povod za ostvarenje svoje namjere. Njegov je suparnik Fran Folnegović, obavljajući javne poslove i dajući svoja mišljenja o nekim situacijama u političkom životu, imao, dakako, i nekih krivih poteza i nespretno formuliranih izjava. Frank je sve to budno pratio, procjenjivao i čekao pogodan trenutak za izvršenje svoga nauma. Folnegović je 21. listopada 1895. na sjednici zagrebačkog Gradskoga zastupstva - osudio postupak hrvatske studentske mladeži, koja je, 16. listopada, za careva i kraljeva boravka u Zagrebu, spalila mađarsku zastavu ispred Jelačićeva spomenika na središnjem zagrebačkom trgu. Frank je zaključio da je ta javno izrečena osuda najveći Folnegovićev politički propust.

\footnotetext{
Naša sloga, Trst, br. 50, 1894., 2.

Naša sloga, Trst, br. 30, 1895., 2.

Hrvatska, Zagreb, br. 163, 1895., 1.

Hrvatska, Zagreb, br. 171, 1895., 1.

Crvena Hrvatska, Dubrovnik, br. 26, 1896., 2.
} 
Ta izjava je bila dovoljno snažan povod za provedbu pripremljenoga plana. Već sutradan je nagovorio onemoćalog Antu Starčevića, Milu Starčevića i Eugena Kumičića, da zajedno s njim istupe iz Stranke prava i da osnuju svoju zasebnu pravašku organizaciju. Uputili su 22. listopada 1895. obavijest predsjedništvu Kluba Stranke prava da istupaju iz tog Kluba i da ustrojavaju svoj „posebni Klub Čiste stranke prava“. Kao razlog svoga istupa istakli su da u Stranci prava postoje neki postupci, koje oni ne odobravaju. Posebno nisu odobravali, nametanje stranci Strossmayerova svojevrsnog protektorata kao i Folnegovićevu izjavu u Gradskom zastupstvu. ${ }^{16}$

lako se tijekom prethodnih godina znalo za nesuglasije među prvacima Stranke prava, taj je raskol za mnoge pravaše bio iznenađujući i zbunjujući čin. Isprva su pojedini pravaši mislili da bi njihova raskoljena stranka ponovno mogla postati jedinstvena, jer su hrvatski interesi, da bi bili ostvareni, trebali hrvatsku pravašku slogu i složno pravaško djelovanje. No, ubrzo se pokazalo da su raskoljeni dijelovi Stranke prava više nespojivi. Svega deset dana nakon izvršenog raskola, 2. studenog 1895., počeo je u Zagrebu izlaziti dnevni list „Hrvatsko pravo" - glasilo Čiste stranke prava. Starčević je bio potpuno pod utjecajem Franka, koji je manipulirao njegovim imenom. lako onemoćao, Starčević izjavljuje kako je "Hrvatsko pravo" glavno pravaško glasilo i da dnevnik "Hrvatska“ više ", ne zastupa njegove misli“. ${ }^{17}$ Od 2. prosinca 1895. dnevni je list „Hrvatska“, glasilo matice Stranke prava, dobio novo ime: „Hrvatska domovina“. Pristaše matice Stranke prava otada će, po tom novom imenu njihova glasila, biti nazivani i domovinašima. Pristaše Čiste stranke prava su, po predsjedniku Josipu Franku, nazivani i frankovcima. Polemike između „Hrvatskog prava“ i „Hrvatske domovine“ bile su vrlo žestoke.

Istarskim i dalmatinskim pravašima nije se nimalo dopadao taj sučeljeni strančarski verbalizam. Oni su imali neutralan stav prema pravaškim frakcijama u Banskoj Hrvatskoj. Isticali su da bi Starčevića trebalo poštedjeti od javnih napada s obzirom na njegove neosporne zasluge i njegovu starost koja ga je onesposobila za neovisno političko djelovanje. O Franku su imali loše mišljenje. Vidjeli su u njemu glavnog arhitekta raskola samo da bi zadovoljio osobnu ambiciju da bude na čelu jedne, sebi privržene pravaške frakcije. Kritizirali su ga kao samoljubivog političara-egocentrika, kojeg je nosila želja za osobnim prvenstvom i dominacijom nad drugima. Naglašavali su da kao takav, nije ni „pravaš, ni hrvatski rodoljub“, te su žalili „one, koji su se za njim poveli“.. ${ }^{18}$

Utemeljitelj, ideolog i dugogodišnji vođa Stranke prava Ante Starčević umro je 28. veljače 1896. u svom zagrebačkom Domu. Umro je "na razvalinama svoga životnog djela“ (Gross 1973: 308). Na njegovu posmrtnom ispraćaju sudjelovalo je mnoštvo pravaša iz obiju banovinskih pravaških frakcija i niz pravaša iz Istre, Dalmacije, Bosne, Hercegovine i slovenskih zemalja. Od istarskih pravaša bili su na posljednjem ispraćaju: Vjekoslav Spinčić, Matko Laginja, Matko Mandić i Dinko Trinajstić. Među vijencima, položenim na Starčevićev grob, nalazila su se i tri vijenca iz Istre, na kojim je pisalo: „Čestitom Hrvatu! - Istarski Hrvati“, "Ocu domovine! - Pazinski Hrvati“ i "Svom velikom dobrotvoru! - Istarska Družba sv. Ćirila i Metoda“. ${ }^{19}$ Mnoštvo Starčevićevih poštovalaca odalo mu je priznanje kao osnivaču i dugogodišnjem vođi Stranke prava, kao borcu za samostalnu i ujedinjenu Hrvatsku i kao čovjeku „koji je sav svoj život i sve svoje sile posvetio sreći i napretku hrvatskoga naroda“. ${ }^{20}$ Domovinaši su mu, u svom nekrologu, klicali: „Slava Ti najveći Hrvatu! Slava neumrlom

\footnotetext{
Hrvatsko pravo, Zagreb, br. 1, 1895., 1.

Hrvatsko pravo, Zagreb, br. 9, 1895., 1.

Crvena Hrvatska, Dubrovnik, br. 43, 1895., 1.

Hrvatska domovina, Zagreb, br. 51, 1896., 1.

Crvena Hrvatska, Dubrovnik, br. 10, 1896., 2.
} 
velikanu Starčeviću!“21 „Naša sloga“ mu je posvetila opširni uvodnik, u kojemu je isticala njegovu viziju cjelovite, slobodne i ujedinjene Hrvatske. ${ }^{22} \mathrm{U}$ pjesmi pod naslovom „Uz smrt neumrlog velikana dra Ante Starčevića“, Istranin Rikard Katalinić Jeretov je isticao:
„Dični starče, što si cielo žiće
hrvatskome žrtvovao rodu,
što si svaku pregorio radost
boreći se za našu slobodu.
Spavaj mirno, viekovi će pozni
kazat jošte potomcima znati
da hrvatstvo podiglo je opet
tvoje geslo: Bog i Hrvati!
Povijest eto tamo na visini
novu zviezdu na nebištu pali,
imenom je tvojim krsti velim
da Te budu i potomci znali! “23

Objavila je „Naša sloga“ i pjesmu Antona Antončića „Prvaku dru Anti Starčeviću“, u kojoj stoji: „Srce puče, al’ ime ostaje“. To slavno Starčevićevo ime, prema pjesnikovoj želji, obvezuje Hrvate da, u njihovu narodnom interesu objedine svoje snage i težnje i da se „nad tim (pokojnikovim) humom" prodiče "složnim sporazmom“. ${ }^{24}$

Koliko je Ante Starčević bio povezan s Istrom i Istranima govori činjenica da je oporučno - od svojega skromnoga novčanog imetka - ostavio Družbi sv. Ćirila i Metoda za Istru tisuću forinti. ${ }^{25}$

Iz Istre je upućeno u Zagreb niz brzojava sućuti, od kojih ističemo one karakteristične. Općina Buzet je u svome brzojavu istakla: „Dao Bog da se na njegovu grobu ujedine stranke“. ${ }^{26}$ Grupa građana iz Buzeta piše: „Budi laka hrvatska zemlja“ tom dičnom „umniku“, koji se uporno borio i druge pokretao u borbu za hrvatska prava "uz geslo: Bog i Hrvati“..27 Skupina vojnih osoba iz Pule, s potpisom: „Rodoljubi kod c. k. bojne mornarice“, javljala je: „Iskazujemo našu sućut nad gubitkom našeg starog Ante!“ Iz Pule je upućen i brzojav Stijepa Gjivića: „Neizmjerni gubitak nek bude poticaj slozi i ljubavi pravih Hrvata, koji se moraju sad najtjesnije spojiti u borbi za sjedinjenje i slobodu. Slava Starome!“ Voloski Hrvati su napisali: „Izvolite primiti najdublje sažaljenje nad gubitkom najvećeg Hrvata svoga doba, pravog zatočnika hrvatskog državnog prava, uskrisitelja hrvatskog imena." Hrvatska općina Žminj je u svom brzojavu naglašavala da smrt štovanog hrvatskog političkog prvaka dr. Ante Starčevća doživljava kao „težak gubitak“. ${ }^{28}$ Brzojav iz Krka, koji su potpisali dr. Vitezić, dr. Volarić, Oršić i Antoničić, glasio je: „Nad grobom slavnog Ante Starčevića i krčki Hrvati gorke suze liju.“ Brzojav iz Kastva, koji je potpisao općinski načelnik Mirko Jelušić u ime „ubave Liburnije“, završio je riječima: „Vječna uspomena dru Anti Starčeviću!“29

\footnotetext{
Hrvatska domovina, Zagreb, br. 49, 1896., 1.

Naša sloga, Trst, br. 10, 1896., 1.

Naša sloga, Trst, br. 10, 1896., 3.

Naša sloga, Trst, br. 15, 1896., 1.

Hrvatska domovina, Zagreb, br. 49, 1896., 2.

Hrvatska domovina, Zagreb, br. 50, 1896., 2.

Hrvatska domovina, Zagreb, br. 51, 1896., 2.

Hrvatska domovina, Zagreb, br. 51, 1896., 3.

Hrvatska domovina, Zagreb, br. 52, 1896., 2.
} 
Za 2. ožujka 1896. (dakle: sutradan nakon Starčevićeve sahrane) održan je pravaški sastanak u dvorani zagrebačkog „Kola“, na kojemu je bilo oko 150 pravaša. Sastanku je predsjedavao Juraj Rukavina, predsjednik Središnjeg odbora Stranke prava. Kad je u dvoranu ušao Josip Frank, Rukavina je napustio predsjedateljsko mjesto i izašao iz dvorane. Unatoč tome, sastanak je održan. Na sastanku su sudjelovali i vodeći pravaši iz Istre: Vjekoslav Spinčić, Matko Laginja, Matko Mandić i Dinko Trinajstić. Među govornicima osobito se istaknuo Vjekoslav Spinčić. On je, kako je zapisano u novinskom izvješću s tog sastanka, „živom i vatrenom rieči“ zagovarao „slogu i mirno razlaganje“. Polemički tonovi u izlaganjima pojedinih govornika pokazali su da do sloge neće doći. Kumičić je okrivljavao domovinaše da su se udaljili od Starčevićeva nauka i isticao da bi se sloga mogla postići jedino vraćanjem na stazu kojom su se kretale Starčevićeve misli. Domovinaši su, ciljajući na Franka, uzvraćali da su neslogu u pravaške redove unijeli pojedinci, koji su radi svojih liderskih ambicija i drugih osobnih interesa zlorabili Starčevićevo ime, Starčevićev nauk i Starčevićevu sve izrazitiju onemoćalost, uvjetovanu bolešću u završnoj dionici njegova života. Braneći svoje istomišljenike, koji su, zajedno sa Starčevićem, istupili iz Stranke prava, navodno zbog sačuvanja Starčevićeva pravaškog nauka, Kumičić je naglašavao: „Budimo Starčevićanci kao što su Muhamedanci po Muhamedu“. ${ }^{30}$

Suparničke strasti su dominirale i bile su glavno obilježje tog sastanka. Uporan, konstruktivan i razborit, kakav je već bio, Spinčić je predložio da se taj sastanak prekine i u mirnijem ozračju nastavi poslije podne u Domu Ante Starčevića. Prijedlog je prihvaćen i sastanak je nastavljen u dogovoreno vrijeme. Na tom poslijepodnevnom sastanku bilo je vidno manje sudionika. Suprotno Spinčićevoj želji da taj sastanak protekne u mirnijoj atmosferi, to se nije ostvarilo. Različita, nepomirljiva stajališta ponovno su došla do izražaja. Spinčić i Laginja su čvrsto zagovarali slogu i uspostavu jedinstva Stranke prava, obrazlažući to interesom hrvatskoga naroda, koji treba jaku političku stranku, čije jakosti ne može biti bez sloge i jedinstva u njezinim redovima. Podržali su ih pojedini domovinaši, ali od Frankovih sljedbenika nitko. Laginja je pozvao Franka „neka za ljubav sloge odstupi isto onako kao i Folnegović". Ali na taj poziv nije bilo odziva. Frank je nakon Starčevićeve smrti i formalno postao predsjednikom Čiste stranke prava. Uvjeren da će stranka ubrzo zadobiti šire prostore u hrvatskom stranačko-političkom životu, Spinčić je, ne odustajući od svoga nastojanja za uspostavu sloge i jedinstva Stranke prava, predložio da se osnuje jedan odbor, koji bi raspravljao o zbliženju i sjedinjenju raskoljenih frakcija i utvrdio načine kako bi se to moglo oživotvoriti. Kumičić se izjasnio protiv Spinčićeva prijedloga i demonstrativno napustio sastanak. Oslanjajući se na dugogodišnje prijateljstvo s Kumičićem, Spinčić je odmah pojurio za njim u namjeri da ga nagovori da se vrati. Kumičić je počeo vikati, govoreći da su njegovi stavovi poznati i da on svoje stavove neće, ne želi i ne može mijenjati. ${ }^{31}$

Kumičićevo incidentno reagiranje neugodno je iznenadilo Spinčića. Potvrda je to poznatoga iskustva i drugih političara kako politika može biti i iznad osobnog prijateljstva pa i uzrok razaranja prijateljskih odnosa među ljudima. Znao je da je Kumičić snažno povezan s Frankom i da su tako međusobno snažno povezane i njihove obitelji. Čvrsta povezanost s Kumičićem (i Kumičićevima) bilo je jako važno Franku. Jer, Kumičić je bio vrlo ugledan književnik i veoma uvažen saborski zastupnik, značajan i u hrvatskoj književnosti i u hrvatskoj politici.

Raskol u banovinskoj Stranci prava bio je - prema doživljaju i ocjeni istarskih pravaša - težak narušavatelj političke snage hrvatskoga naroda. Taj je raskol koristio jedino neprijateljima i protivnicima Hrvata i hrvatske državotvorne misli. Kao i dalmatinski

\footnotetext{
Hrvatska, Zagreb, br. 52, 1896., 3.

31 Hrvatska, Zagreb, br. 52, 1896., 3.
} 
pravaši, tako su i istarski pravaši izrazili svoju neutralnost: da se neće opredjeljivati ni za jednu pravašku frakciju u Banskoj Hrvatskoj. lako se javno nisu opredjeljivali, ipak im je bila bliskija domovinaška frakcija, u čijim su redovima ostali brojni zaslužni prvaci Stranke prava iz vremena prije raskola. Frank im nije bio nimalo simpatičan. Za njih je on bio samoljubiv i častohlepan čovjek koji je izvršio raskol u Stranci prava u ime tobožnje čistoće starčevićanskih načela, učvršćivao taj raskol i onemogućavao da se ponovno uspostavi jedinstvo pravaških redova, osporavali su čistoću namjera i gledali u njemu antistarčevićanca.

Tadašnje političke prilike u svim dijelovima hrvatskog nacionalnog prostora nisu bile nimalo povoljnije od političkih prilika u prethodnim godinama. Dominirajući Talijani i protalijani u Istri stvarali su nova uporišta pomoću kojih bi se još jače suprotstavljali težnjama istarskih Hrvata da se zbliže i ujedine s ostalim hrvatskim zemljama. Jedno od tih novih talijanskih i protalijanskih uporišta bio je i Ivan Krstić, koji se doselio iz zadarskih Arbanasa u liburnijski dio Istre i tu - suprotno političkom djelovanju "Naše sloge“ - izdavao od početka 1896. list pod naslovom „Prava naša sloga“, kojim se zauzimao za istarsko autonomaštvo (Šetić 2005: 69). U Dalmaciji - suprotno hrvatskoj političkoj misli - bujalo je uz talijanskoprotalijansko i srpsko autonomaštvo, što se vidjelo i po aktivnosti tiska Autonomaške (talijansko-protalijanske) i Srpske stranke i po izbornim koalicijama tih stranaka u općinskim i saborskim izborima. Nakon raskola u banovinskoj Stranci prava dolazilo je do podvajanja i među dalmatinskim pravašima. U Zadru se Ivo Prodan sve otvorenije priklanjao politici Frankove Čiste stranke prava, a u Dubrovniku se - kao oponent agilnoj Supilovoj „Crvenoj Hrvatskoj" - pojavio list „Pravo“, koji je kao tjednik kratko izlazio tijekom 1895. i 1896. godine (Perić 1980: 20). Spinčić i Laginja su, kao narodnjaci i pravaši, budno pazili da se održi sloga u redovima istarske Hrvatsko-slovenske narodne stranke. Jer, bez te bi sloge i istarski Hrvati i istarski Slovenci postali slabiji. Sloga je bila njihova snaga i s tom udruženom snagom bivali su jači u borbi za svoja narodna prava.

S obzirom na to da je nakon raskola u banovinskoj Stranci prava ostao u svojoj funkciji svepravaški Središnji odbor, njegov je predsjednik Juraj Rukavina sazvao sastanak odbora za 29. travnja 1896. u Zagrebu. Držeći da je taj odbor i legalan i legitiman, istarski i dalmatinski pravaši, zastupnici u Carevinskom vijeću u Beču: Vjekoslav Spinčić, Matko Laginja, Juraj Biankini, Virgil Perić i Nikola Dapar uputili su iz Beča 7. ožujka 1896. svoj javni poziv svim članovima tog odbora da dođu na taj sastanak i da se na njemu izjasne za ponovno uspostavljanje jedinstva pravaških redova. ${ }^{32}$

Postojanje dviju pravaških stranaka u Banskoj Hrvatskoj: domovinaške Stranke prava i Čiste stranke prava bila je stvarnost, koja se više, kako je bilo očito, nije dala izmijeniti. Ti su neuspjesi razočaravali istarske pravaše. Ostajala im je jedino utjeha da su se iskreno i uporno zalagali da slože i ujedine ono, što je - kako su se uvjerili - postalo nesloživo i neujedinjivo.

32 Hrvatska, Zagreb, br. 59, 1896., 1. 


\section{POPIS LITERATURE}

\section{DIKLIĆ 1995}

Marjan Diklić, „Stranka prava u Dalmaciji povodom 100. obljetnice osnutka (1894. - 1994.)“, Radovi Zavoda za povijesne znanosti HAZU u Zadru, 37, Zadar 1995., 779-791.

\section{GROSS 1973}

Mirjana Gross, Povijest pravaške ideologije, Zagreb 1973.

\section{HORVAT 1990}

Josip Horvat, Ante Starčević. Kulturno-povijesna slika, Zagreb 1990. (drugo izdanje)

\section{MANIN 2005}

Marino Manin, „Hrvatski nacionalni pokret u Istri na početku 20. stoljeća", Povijest Hrvata. Druga knjiga: od 15. stoljeća do kraja Prvog svjetskog rata, (gl. ur. Mirko Valentić i Lovorka Čoralić), Zagreb 2005.

\section{MATKOVIĆ 2001}

Stjepan Matković, Čista Stranka prava 1895.1903., Zagreb 2001.

\section{MILOVAN ET AL. 2008}

Iva Milovan i Nevio Šetić, „Dva općehrvatska skupa iz 1890. i 1893. i njihovo nacionalno-in- tegracijsko značenje", Anali Zavoda za povijesne znanosti HAZU u Dubrovniku, XLVI, Dubrovnik 2008., 227-258.

\section{PERIĆ 1980}

Ivo Perić, Dubrovačka periodika 1848.-1918., Dubrovnik 1980.

\section{PERIĆ 2009}

Ivo Perić, Politička oporba u Banskoj Hrvatskoj 1880. - 1903., Zagreb 2009.

\section{STRČIĆ 1976/77}

Petar Strčić, „O pravaštvu u Istri i na Kvarnerskim otocima krajem 60-tih i 70-tih godina 19. stoljeća“, Historijski zbornik, Zagreb 1976/77.

\section{STRČIĆ 1988}

Petar Strčić, „Počeci organiziranog političkog pokreta u Istri u XIX. stoljeću“, Jugoslovenski istorijski časopis, 4, Beograd 1988.

\section{ŠETIĆ 2005}

Nevio Šetić, O povezanosti Istre s ostalim hrvatskim zemljama. Naša sloga 1870. - 1915., Zagreb 2005.

\section{SAŽETAK}

Pripadnici mlađeg naraštaja istarskih preporoditelja (u kojemu su imali vodeću ulogu Vjekoslav Spinčić, Matko Laginja i Matko Mandić) nastavili su svoje djelovanje u istarskoj Hrvatsko-slovenskoj narodnoj stranci, nastaloj 1878., ali su prihvatili i ideologiju Stranke prava u banovinskoj Hrvatskoj, osnovanoj 1861., koja je uključivala i Istru u okvir buduće slobodne, samostalne i ujedinjene Hrvatske te su djelovali i kao pravaši.

Raskol u banovinskoj Stranci prava, izvršen 1895. godine, teško im je pao. Od dotad jedinstvene stranke nastale su otada njezine dvije frakcije: Stranka prava, koja je izdavala svoje glasilo „Hrvatsku domovinu“, i Čista stranka prava, koja je izdavala svoje glasilo „Hrvatsko pravo“. Taj je raskol (za koji je bio najviše kriv Josip Frank, utemeljitelj Čiste stranke prava) oslabio hrvatsku oporbu u Banskoj Hrvatskoj.

Istarski pravaši, cijeneći slogu i jedinstvo i u stranačko-političkom životu, uporno su se zalagali da se banovinski pravaši opet slože i ujedine $u$ interesu hrvatskoga naroda. $U$ tom svom nastojanju nisu uspjeli. Nisu se priklonili ni jednoj od dviju banovinskih pravaških frakcija. 


\section{SUMMARY}

\section{Relation of the Istrian Members of the Party of Rights Toward the Disunion in the Party of Rights in Ban's Croatia of 1895}

The members of the younger generation of the Istrian reformists (in which Vjekoslav Spinčić, Matko Laginja and Matko Mandić played the leading role) continued their activity in the Istrian Croatian - Slovenian People's Party, founded in 1878, but they also accepted the ideology of the Party of Rights in the Ban's Croatia, established in 1861, which also included Istria in the frame of the future free, independent and unified Croatia, and they also acted as the Party of Rights members.

The disunion in the Party of Rights in Ban's Croatia, which came to pass in 1895, was a hard blow for them. The party, solid until then, divided into two parties: Party of Rights, which issued its bulletin "Croatian Homeland", and Pure Party of Rights, which issued a bulletin of its own, "Croatian Right". This division (for which Josip Frank, the founder of the Pure Party of Rights was to blame) has weakened the Croatian opposition in the Ban's Croatia.

Istrian Party of Rights members, who valued the harmony and unity in the party and political life, were adamant in their attempts to unify the members of Party of Rights again, in the interest of Croatian people. They failed in these attempts, but they did not choose neither of these two party fractions in Ban's Croatia.

Keywords: Party of Rights, Ante Starčević, Fran Folnegović, Josip Frank, Vjekoslav Spinčić, Ban's Croatia, Istria 